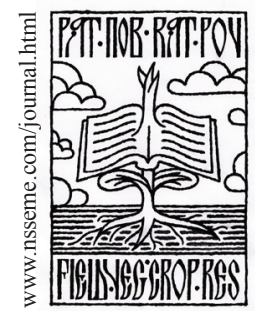

\title{
The Issue of Determining the Amount of Deposited Nitrogen Compounds in Salt-Affected Habitats within the National Ecological Network
}

\author{
Vesna Kicošev · Jovica Vasin • Milan Kvaščev • Miloš Bibin • \\ Ivan Bošnjak · Dragan Đukić · Laslo Senji
}

received: 12 March 2014, accepted: 14 May 2014

published online: 19 June 2014

(C) 2014 IFVC

doi:10.5937/ratpov51-5659

\begin{abstract}
Summary: The exceedance in the critical load of nitrogen compounds is used by the European Environment Agency as an indicator of the biodiversity loss risk. This paper provides a general overview of continental saline habitats vulnerability (Slatine - in Serbian) located in central Banat within the National Ecological Network, caused by the deposition of nitrogen compounds. These compounds originate from manure of selected category of animals raised in settlements located in the vicinity of protected areas. The data on short-range deposition of nitrogen compounds within two zones were used for determining the areas of impact: the zone of probable impact $(0-500 \mathrm{~m})$ and the zone of potential impact $(500-2000 \mathrm{~m})$. According to the calculation results, the most vulnerable locations which, for the most part, belong to "Rusanda" protected area, are the pastures directly surrounding village Kumane, pastures bordering Rusanda salty lake, including the lake itself.

Keywords: Banat region, deposition, ecological network, nitrogen compounds, protected areas, salt-affected habitats
\end{abstract}

\section{Introduction}

Nitrogen compounds deposition throughout Europe is a major problem in the protected areas, alongwith high spatialvariability ofimpactintensity and significant differences in responses of National policies of the European Union (EU) countries

\section{Kicošev*}

Institute for Nature Conservation of Vojvodina Province, 20a Radnička, 21000 Novi Sad

e-mail:vesna.kicosev@pzzp.rs

J. Vasin

Institute of Field and Vegetable Crops, 30 Maksima Gorkog, 21000 Novi Sad

M. Kvaščev

Ecological Society “Mutljača”, 23271 Kumane

M. Bibin

Manager of Protected Area „Okanj bara“, 23208 Elemir

I. Bošnjak

Veterinary service „Braća Bošnjak Divet“, 23270 Melenci

D. Đukić

Veterinary service „Pega“, 23208 Elemir

L. Senji

Manager of Protected Area „Slano kopovo“, 23272 Novi Bečej
(Kicošev et al. 2011a). It is believed that by the end of 2020, 64\% of natural ecosystems across the EU will have been under threat from excessive nutrient deposition, particularly from nitrogen (CCE 2008). Nitrogen compounds with high risk of contamination mainly appear in the form of ammonium resulting from agricultural activities, and nitrogen oxides emitted from industrial sources. Globally, nitrogen compounds deposition (N deposition) has been ranked as the most important land use and climate change driver, but regionally, in the Northern Temperate Zone, it is expected to be a major driver of biodiversity change (Sala et al. 2000). The influence of eutrophication on the habitats of the ecological network results in the changes of species composition, reduction in biodiversity, loss of priority and endangered species, as well as deterioration of ecosystem services. Damaged and/or degraded ecosystems as entireties have decreased tolerance towards the changes in the environment (Noss 2001). The protection of spatial units, characterized by preserved natural areas and conditions necessary for the survival of priority and endangered species is provided by establishing protected areas (Kicošev \& Sabadoš 2007). Connecting them into regional and 
continental networks is one of the priorities of Contemporary Conservation Biology (Hannah et al. 2002). The connection is achieved within the project "Natura 2000" at the EU level (Hicks et al. 2011, Stoica et al. 2012), and through the establishment of National Ecological Networks at countries level (Kicošev et al 2011b). The main components of the National Ecological Network are saline habitats of the Pannonian region (Pannonian salt steppes and salt marshes, EUNIS classification: E:6.21). Pannonian salt steppes and salt marshes, which were the dominant type of natural primeval vegetation in Vojvodina, are evaluated (under Code 1530) as Priority Natural Habitat Types (Directive on Habitats - Directive 92/43/EEC Annex I) in EU countries. Since oligotrophic plant communities occur in these habitats, they belong to the types of habitats most sensitive to high amounts of deposited nitrogen (Kicošev et al. 2012). Salt habitats are often located in agricultural environment and those which are used as pastures are mostly surrounded by farms. Ammonium released from the farms is mostly deposited in the nearby habitats, often in phytotoxic concentrations. From the perspective of spatial distribution of the released polluting matter, the literature (Sutton et al. 2009) specifies two extremes in the nitrogen deposition issue: long range $(50-100 \mathrm{~km})$ and short range $(<2 \mathrm{~km})$. It was also determined that the majority of impacts occur less than $500 \mathrm{~m}$ from the source (Pinho et al. 2009). Impacts of nitrogen deposition depend on climatic factors, and therefore the change in climatic factors will probably influence deposition (at the local level, climatic changes may intensify or mitigate the consequences of $\mathrm{N}$ deposition).

\section{Objectives and Tasks of the Study}

The main objective of this study was to make a general overview of the vulnerability of saline habitats included in the National Ecological Network caused by the deposition of nitrogen compounds from manure, using protected areas in central Banat, Serbia as an example. Since the aim of this study is related to emphasise the consequences of improper storage of manure on the protected areas, and not to obtain accurate data on the deposited nitrogen mass per unit area, available field data with acceptable level of accuracy were used (more details in the section Materials and Methods).

The research task arises from the results of local population survey conducted in the settlements surrounding the Special Nature Reserve (SNR) "Okanj bara" and Nature Park (NP) "Rusanda" for the purpose of analysing stakeholders in order to establish protected areas. In fact, the survey results show that local population is interested in cooperation in the area of nature and environment protection as the basis for the sustainable rural development. Representatives of local population have emphasised the consequences of illegal storage of manure in terms of security and health, and the majority of surveyed respondents agreed that there was a need for a comprehensive solution to this problem (Kicošev et al. 2011c). Since the funds allocated to this field of economy are insufficient for the integral solution to the problem (Kicošev et al. 2012), it is necessary to register particularly vulnerable areas. For the abovementioned reasons, when assessing the vulnerability of habitats to nitrogen deposition, special emphasis was put on the sites of protected areas where, under the present conditions, the possibility of exceedance of limit values had been determined.

\section{Materials and Methods}

The study was conducted on the territory comprisingsalinehabitats (complex ofsaltsteppes and salt marshes), which is a part of the central Banat ecological network together with central areas covering the SNR "Okanj bara" and the SNR "Slano kopovo" (protected areas) and the NP "Rusanda" (area in the process of protection by competent authorities). Settlements in the territory of the City of Zrenjanin (Melenci, Elemir, Taraš) and the Municipality of Novi Bečej (Novi Bečej and Kumane) surround protected areas. Most of the population of these settlements (except Novi Bečej) makes a living from agriculture, with animal husbandry being the most prominent in Kumane, wherefrom a significant number of cattle and sheep graze on salt habitats (Kicošev et al. 2011b). Pastures directly surrounding Kumane connect SNR "Okanj bara" and NP "Rusanda". In fact, the dividing line between these two protected areas is located in the part of pasture areas southeast of Kumane (Fig. 1). In terms of nitrogen deposition, such state indicates that the same sites may be harmful for both natural resources with different expected impact intensity, depending on their position in space, direction of prevailing winds and so forth. Possible vulnerability of habitats to manure depots results from an inadequate manure management in buildable and non-buildable lands in all five cadastral municipalities.

Values related to pasture areas in the protected sites were used from the corresponding 


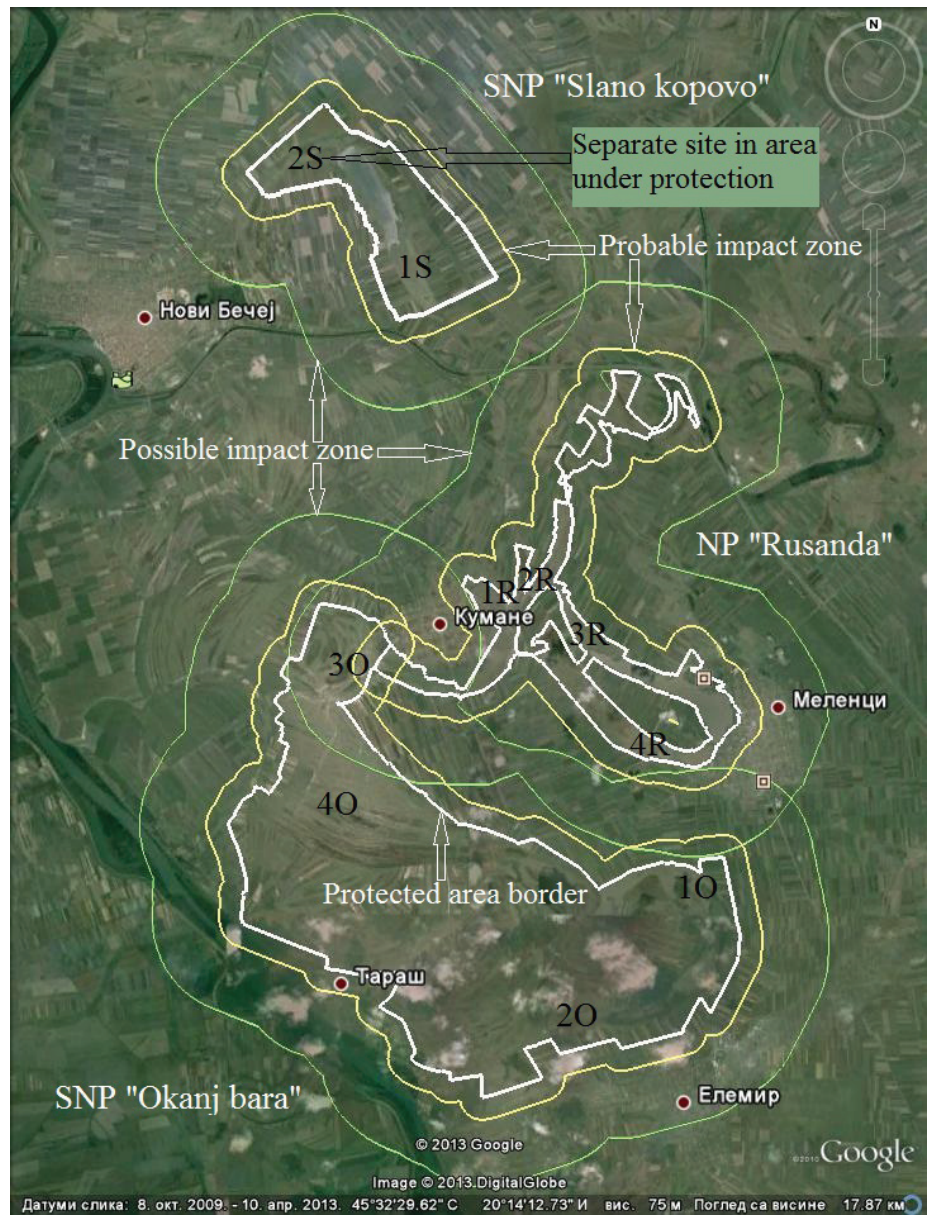

Figure 1. Overview of protected areas with projected impact areas and isolated sites with increased risk from the consequences of nitrogen deposition

protection studies (Kicošev et al. 2012, Pavkov 1999, Panjković \& Kovačev 2011). Data on the number of livestock animal units on the pastures, granges and in settlements were obtained from the local Grazing Committees and the competent veterinary services. Data on individual facilities for keeping livestock animals are available for cattle, sheep, pigs, poultry and goats, while only aggregate data are available for other animals and only in some settlements. For this reason, other animals were not included in this calculation. The choice of animal species for which the data were collected was conducted on the basis of available references (DEFRA 2009) on pasture capacities, which were defined according to the number of livestock per area unit (ha) and potential nitrogen load. Calculation for possible nitrogen load was made by using the data on the potential content of nitrogen in manure and on the basis of an estimated content of nitrogen emitted from manure. The equation [1] was used to calculate the total amount of nitrogen originating from manure generated by animals included in this research in the study area. The aggregate value of total nitrogen emission was obtained as a sum of $\mathrm{N}$ values emitted from the estimated available amount of manure from each settlement, and manure amount was calculated according to the literature data (DEFRA 2009) for individual animal species:

$\Sigma \mathrm{Nm}(\mathrm{j})[\mathrm{kgN} /$ year $]=\Sigma \mathrm{Bp}(\mathrm{j}) \mathrm{xKm}_{\mathrm{N}}(\mathrm{j})[1]$, wherein: $\Sigma \mathrm{Nm}=$ aggregate amount of total nitrogen in the manure expressed as weight

$\mathrm{j}=$ particular livestock species: cattle (c), sheep (s), pigs $(\mathrm{pi})$, poultry $(\mathrm{pl})$ and goats $(\mathrm{g})$

$\Sigma \mathrm{Bp}=$ total number of livestock in the selected area $\mathrm{Km}_{\mathrm{N}}=$ the coefficient related to the total nitrogen content in the livestock manure production rates

The $\mathrm{Km}_{\mathrm{N}}$, which differs in literature from species to species, as well as within a species itself (depending on the weight, age, etc.), was selected on the basis of the most frequent data obtained from the field study. For example, for cows (for which 
milk yield is 6000-9000 l) $\mathrm{Km}_{\mathrm{c}}$ is $101 \mathrm{kgN} /$ year, and for pigs (weighing 66-150 kg) $\mathrm{Km}_{\mathrm{pi}}$ is $12 \mathrm{kgN} /$ year and so forth.

$$
\begin{aligned}
& \mathrm{Km}_{\mathrm{N}}(\text { cattle })=\mathrm{Km}_{\mathrm{c}}=101 \mathrm{kgN} / \text { year } \\
& \mathrm{Km}_{\mathrm{N}}(\text { sheep })=\mathrm{Km}_{\mathrm{s}}=11.9 \mathrm{kgN} / \text { year } \\
& \mathrm{Km}_{\mathrm{N}}(\text { pigs })=\mathrm{Km}_{\mathrm{pi}}=12 \mathrm{kgN} / \text { year } \\
& \mathrm{Km}_{\mathrm{N}}(\text { poultry })=\mathrm{Km} \mathrm{p}_{\mathrm{p}}=0.33 \mathrm{kgN} / \text { year } \\
& \mathrm{Km}_{\mathrm{N}}(\text { goats })=\mathrm{Km}_{\mathrm{g}}=15 \mathrm{kgN} / \text { year }
\end{aligned}
$$

Calculation of the possible $\mathrm{N}$ deposition in some parts of the protected areas was made using digitally processed data on the number of particular livestock animal species within the zone of impact in the protected areas. Minimal value selection of the number of particular animal species for digitalization purposes was carried out in accordance with the criteria for the construction of manure disposal facilities, as well as the sensitivity of protected sites to eutrophication. For instance, according to the data from the most elaborate international project made in this field so far (which includes our country as well), the pre-requisite for the construction of the manure disposal facility is the provision of minimum 18 animal units (MPŠV 2011). For the purpose of the research concerned, the minimal number of animals is 10-15, depending on the type of animal and the vicinity of vulnerable ecosystems. Poultry is an exception for which the minimal number is 1,000 , in compliance with the established rules for nitrogen calculation (DEFRA 2009). Such selection of data for digitalization, in addition to clarity of the presented content, enabled obtaining accurate data for the purpose of preservation and conservation of the area. Locations of the facilities for keeping livestock within and outside the buildable lands are digitalized on the basis of available high resolution orthophoto and satellite images in Google Earth Pro programme, providing data on distances between the facilities and the border of protected areas, as well as their position in relation to different parts of the protected area with respect to the established directions of prevailing winds and data on frequency at the established sites within the given zone. The literature value (Ketterings et al. 2005, CACES 2012, Vall \& Vidal 2013) for the assessment of emitted nitrogen from improperly stored manure is used uniformly and represents at least $50 \%$ of its total mass in the manure. For the abovementioned reasons, this paper also did not analyse in particular the manure of individual animal species from the perspective of manure evaporation speed or microclimatic factors related to the temperature and humidity. Data on direction and frequency of the winds were obtained by analysing the wind rose for the City of Zrenjanin (Katić 2008). In order to calculate the total amount of nitrogen emitted from manure, for which possibility of deposition in the protected area was determined, the following equation has been set:

$\Sigma \mathrm{Nm}_{\tau}(\mathbf{j})[\mathrm{kgN} / \operatorname{god}]=\Sigma \mathrm{Bp}(\mathbf{j}) \mathrm{xKm}_{\mathrm{N}}(\mathbf{j}) \mathrm{xP}_{\tau}[2]$, $\mathbf{P}_{\tau}(\%)=\left(50-\mathbf{d}_{\tau}\right) \%$, wherein:

$\Sigma \mathrm{Nm}_{\tau}=$ aggregate amount of total nitrogen with the possibility of deposition in the protected area, expressed as mass

$\mathrm{P}_{\tau}=$ percent of nitrogen with the possibility of deposition in the protected area

$50=$ percent of nitrogen evaporating from the manure

$\mathrm{d}_{\tau}=$ additional percent of nitrogen with the possibility of deposition outside the protected area

$\mathrm{d}_{\tau}=f \quad$ (frequency and direction of prevailing winds, estimated frequency of the established sites within the given area and their position with respect to the protected site)

For determining the preservation status of a habitat, it is important to assess the load limit for nitrogen deposition impact. Exceedance of critical load of nitrogen compounds is used by the European Environment Agency as an indicator of biodiversity loss risk (EEA 2007). While assessing the limit of load values, all reactive forms of deposited nitrogen are regarded as equal according to their impact on ecosystems (Arbejdsrapport 2000). According to the literature data, the approximate value of the load limit for pastures is $170 \mathrm{kgN} / \mathrm{ha}$ (DEFRA 2009). Bearing in mind that the concentration of certain substances (such as ammonia) can still exceed the tolerance level for highly sensitive species (Bobbink \& Hettelingh 2011), lower value should be adopted for saltaffected pastures as oligotrophic habitats.

In order to identify the impact area (IA), data on short-range nitrogen deposition within two zones were used: the probable impact zone stretching from the border of the protected area up to 500 $\mathrm{m}$ and the possible impact zone from $500 \mathrm{~m}$ to $2000 \mathrm{~m}$. The probable impact zone, within which most of the impacts occur, overlaps the minimal dimension adopted for the design of protective belts of natural areas which were declared protected in the period after the adoption of the Law on Environmental Protection ("Official Gazette of the Republic of Serbia” No. 36/2009, 88/2010, 91/2010-correction) and the Regulation on the Ecological Network (Official Gazette of RS, 
102/2010) (Kicošev et al. 2013).

A geographical map showing the impact area (Fig. 1) was obtained by transferring the geographical data from GIS application (a set of computer programmes designed to help users) to the satellite background (Google maps) by means of pre-design and data conversion (feature alterations). Zone areas of probable and possible impact (impact area) were obtained by geoprocessing of the vector display of protected areas in the "shp file" format, defining the parameter for the distance function $(500 \mathrm{~m}$ and $2000 \mathrm{~m})$ from a single vector (border of the protected area). Data obtained by designing the impact area are highly accurate since the borders of protected areas (used as a basis) were obtained through the digitalization of cadastral maps $(\mathrm{P}=1: 2500)$ in the ArcGIS 10 software package.

\section{Results and Discussion}

The calculation results, obtained by usingdigitally processed data (spatially and computationally) on the number of livestock within the area of impact on the protected zone, are shown in Table 1. The table comprises data related to the situation in the area under protection (AUP), probable impact zone (PRIZ) and possible impact zone (POIZ) classified according to the registered number of livestock (cattle, sheep, pigs, poultry and goats) and the estimated content of nitrogen, considering the direction of prevailing winds (PW) and periods of lower wind frequency in the studied area. The periods of low level winds were shown separately for the parts of areas from which prevailing winds do not blow towards the protected area, and they were marked as: without prevailing direction (WPD). If in certain locations in the settlements a minimal number of livestock necessary for geo-referencing were not registered (which was commonly the case with poultry and goats), such field in the table contains OSS data (outside the specified scope). Since results of calculation for the amount of nitrogen with the possibility of deposition in the protected area represent approximate values, additional percentage of nitrogen $\left(d_{\tau}\right)$ was obtained by rounding off the calculation results $(1,5,10, \ldots, 45, \ldots, 80)$, so

Table 1. Aggregate amount of total nitrogen originating from livestock manure in the protected areas and within the impact area with the possibility of deposition in salt habitats

\begin{tabular}{|c|c|c|c|c|c|c|c|c|c|c|c|c|c|c|c|c|c|c|c|}
\hline \multirow{2}{*}{$\begin{array}{l}\text { Protected } \\
\text { Area (PA } \\
\text { NP }\end{array}$} & \multicolumn{2}{|l|}{ Location } & \multirow{2}{*}{\begin{tabular}{|l|}
$\mathrm{PW}$ \\
$\mathrm{SE}, \mathrm{W}, \mathrm{NW}$ \\
\end{tabular}} & \multirow{2}{*}{\begin{tabular}{r|}
$\mathrm{Bpc}$ \\
370 \\
\end{tabular}} & \multirow{2}{*}{\begin{tabular}{|r|}
$\mathrm{Pt}(\%)$ \\
75 \\
\end{tabular}} & \multirow{2}{*}{\begin{tabular}{|l}
$\begin{array}{l}\Sigma \mathrm{Nmc} \\
(\mathrm{kgN} / \mathrm{yr})\end{array}$ \\
28028 \\
\end{tabular}} & \multirow{2}{*}{\begin{tabular}{|r|}
$\Sigma$ Bps \\
200 \\
\end{tabular}} & \multirow{2}{*}{\begin{tabular}{|r|}
$\mathrm{Pt}(\%)$ \\
80 \\
\end{tabular}} & \multirow{2}{*}{\begin{tabular}{|l|}
$\begin{array}{l}\Sigma \mathrm{Nms} \\
(\mathrm{kgN} / \mathrm{yr})\end{array}$ \\
1920 \\
\end{tabular}} & \multirow{2}{*}{\begin{tabular}{r|}
$\Sigma \mathrm{Bppi}$ \\
$\mathrm{NF}$ \\
\end{tabular}} & \multirow{2}{*}{\begin{tabular}{c|}
$\mathrm{Pt}(\%)$ \\
$/$ \\
\end{tabular}} & \multirow{2}{*}{\begin{tabular}{|l|}
$\begin{array}{l}\Sigma \mathrm{Nmpi} \\
(\mathrm{kgN} / \mathrm{yr})\end{array}$ \\
$/$ \\
\end{tabular}} & \multirow{2}{*}{\begin{tabular}{|r|}
$\Sigma \mathrm{Bppl}$ \\
$\mathrm{NF}$ \\
\end{tabular}} & \multirow{2}{*}{\begin{tabular}{|c|}
$\mathrm{Pt}(\%)$ \\
$/$ \\
\end{tabular}} & \multirow{2}{*}{\begin{tabular}{|l|}
$\begin{array}{l}\Sigma \mathrm{Nmpl} \\
(\mathrm{kgN} / \mathrm{yr})\end{array}$ \\
$/$ \\
\end{tabular}} & \multirow{2}{*}{\begin{tabular}{|c|}
$\Sigma \mathrm{Bpg}$ \\
$\mathrm{NF}$ \\
\end{tabular}} & \multirow{2}{*}{\begin{tabular}{|c|}
$\mathrm{Pt}(\%)$ \\
$/$ \\
\end{tabular}} & \multirow{2}{*}{\begin{tabular}{|l|}
$\begin{array}{l}\Sigma \mathrm{Nmg} \\
(\mathrm{kgN} / \mathrm{yr})\end{array}$ \\
$/$ \\
\end{tabular}} & \multirow{2}{*}{\begin{tabular}{|l|}
$\begin{array}{l}\Sigma \mathrm{Nm} \\
(\mathrm{kgN} / \mathrm{yr})\end{array}$ \\
29948 \\
\end{tabular}} \\
\hline & AUP & & & & & & & & & & & & & & & & & & \\
\hline \multirow[t]{7}{*}{ "Rusanda" } & PRIZ & Melenci & SE & 173 & 30 & 5242 & 810 & 25 & 2430 & 262 & 25 & 786 & 13000 & 40 & 1716 & OSS & 1 & 1 & 10174 \\
\hline & PA-500 m & Kumane & $\mathrm{W}, \mathrm{NW}$ & 740 & 35 & 26159 & 280 & 40 & 1344 & 705 & 30 & 2538 & OSS & 1 & 1 & OSS & 1 & 1 & 30041 \\
\hline & & $\Sigma(\mathrm{PA}-500 \mathrm{~m})$ & & & & & & & & & & & & & & & & & 40215 \\
\hline & POIZ & Melenci & $\mathrm{SE}$ & 885 & 5 & 4470 & 2125 & 10 & 255 & 2364 & 10 & 284 & 45000 & 5 & 743 & OSS & 1 & 1 & 5725 \\
\hline & $500-2000 \mathrm{~m}$ & Kumane & $\mathrm{W}, \mathrm{NW}$ & 1240 & 10 & 125 & 450 & 10 & 54 & 120 & 10 & 14 & OSS & 1 & 1 & OSS & 1 & 1 & 193 \\
\hline & & $\Sigma(500-2000 \mathrm{~m})$ & & & & & & & & & & & & & & & & & 5945 \\
\hline & Total & $\Sigma($ AUP + IA $)$ & & & & & & & & & & & & & & & & & 76108 \\
\hline \multirow{10}{*}{$\begin{array}{l}\text { SNR } \\
\text { "Okanj } \\
\text { bara" }\end{array}$} & AUP & & SE,W,NW & 1480 & 80 & 119548 & 600 & 75 & 5400 & $\mathrm{NF}$ & 1 & 1 & $\mathrm{NF}$ & 1 & 1 & OSS & 1 & 1 & 124984 \\
\hline & PRIZ & Melenci & WPD & 60 & 15 & 909 & OSS & 1 & 1 & OSS & 1 & 1 & 10000 & 20 & 660 & OSS & 1 & 1 & 1569 \\
\hline & PA-500 m & Kumane & WPD & 880 & 10 & 8888 & OSS & 1 & 1 & OSS & 1 & 1 & OSS & 1 & 1 & OSS & 1 & 1 & 8888 \\
\hline & & Taraš & $\mathrm{SE}, \mathrm{W}, \mathrm{NW}$ & 270 & 45 & 8181 & 540 & 40 & 1620 & OSS & 1 & 1 & OSS & 1 & 1 & 70 & 30 & 315 & 10116 \\
\hline & & $\Sigma(\mathrm{PA}-500 \mathrm{~m})$ & & & & & & & & & & & & & & & & & 20573 \\
\hline & POIZ & Melenci & WPD & 60 & 1 & 61 & 475 & 1 & 57 & 2384 & & 286 & 45000 & & 149 & OSS & 1 & 1 & 553 \\
\hline & $500-2000 \mathrm{~m}$ & Kumane & WPD & 830 & 1 & 838 & 230 & 1 & 28 & 825 & 1 & 99 & $\mathrm{NF}$ & 1 & 1 & OSS & 1 & 1 & 965 \\
\hline & & Elemir & SE & 814 & 10 & 8221 & 655 & 10 & 786 & OSS & 1 & 1 & OSS & 1 & 1 & OSS & 1 & 1 & 9607 \\
\hline & & $\Sigma(500-2000 \mathrm{~m})$ & & & & & & & & & & & & & & & & & 11125 \\
\hline & Total & $\Sigma(\mathrm{AUP}+\mathrm{IA})$ & & & & & & & & & & & & & & & & & 156682 \\
\hline \multirow{7}{*}{$\begin{array}{l}\text { SNR } \\
\text { "Slano } \\
\text { kopovo" }\end{array}$} & AUP & & SE,W,NW & 100 & 80 & 8080 & 240 & 80 & 2304 & $\mathrm{NF}$ & 1 & 1 & $\mathrm{NF}$ & 1 & 1 & $\mathrm{NF}$ & 1 & 1 & 10384 \\
\hline & PRIZ & Novi Bečej & W] & 135 & 45 & 6136 & $\mathrm{NF}$ & 1 & 1 & $\mathrm{NF}$ & 1 & 1 & $\mathrm{NF}$ & 1 & 1 & $\mathrm{NF}$ & 1 & 1 & 6136 \\
\hline & PA-500 m & $\Sigma(\mathrm{PA}-500 \mathrm{~m})$ & & & & & & & & & & & & & & & & & 6136 \\
\hline & POIZ & Kumane & SE & 70 & 5 & 354 & $\mathrm{NF}$ & 1 & 1 & $\mathrm{NF}$ & 1 & 1 & $\mathrm{NF}$ & 1 & 1 & $\mathrm{NF}$ & 1 & 1 & 354 \\
\hline & $500-2000 \mathrm{~m}$ & Novi Bečej & $\mathrm{W}$ & 240 & 1 & 242 & 240 & 1 & 29 & $\mathrm{NF}$ & 1 & 1 & $\mathrm{NF}$ & 1 & 1 & $\mathrm{NF}$ & 1 & 1 & 271 \\
\hline & & $\Sigma(500-2000 \mathrm{~m})$ & & & & & & & & & & & & & & & & & 625 \\
\hline & Total & $\Sigma(\mathrm{AUP}+\mathrm{IA})$ & & & & & & & & & & & & & & & & & 17145 \\
\hline
\end{tabular}

Legend: AUP=Area under protection; IA=Impact area: PRIZ(probable impact zone)+POIZ(possible impact zone); $\Sigma \mathrm{Bp}=$ Total number of livestock in the selected area: c-cattle, s-sheep, pi-pigs, pl-poultry, g-goats; OSS=Outside the specified scope; $\mathrm{NF}=\mathrm{Not}$ found; $\Sigma \mathrm{Nm}=$ Aggregate amount of total nitrogen in manure; PW=Prevailing winds: SEsouth-eastern, W-western, NW-north-western; WPD $=$ Without prevailing direction 
that display of results itself would show that the obtained values are relative.

The results in Table 1 show the significant possible load of NP "Rusanda" which might occur as a result of nitrogen deposition. Compared to the SNR "Okanj bara" (4026 ha), four times smaller pasture area (1013 ha) bears only half as much load $(76108 \mathrm{kgN} /$ year, in comparison to 156682 $\mathrm{kgN} /$ year). The main cause for such situation most certainly lies in the fact that the amount of potentially deposited nitrogen from the probable impact zone (up to $500 \mathrm{~m}$ ) is twice as high for NP "Rusanda" (40215 kgN/year) than for SNR "Okanj bara" (20573 kgN/year).

The aggregate amount of total nitrogen shown by settlements (Tab. 2) refers to the manure content from all livestock included in this research, regardless of the number of particular animal species per site. According to the data, settlement with the largest amount of manure (Kumane) contains more than 360 tons of nitrogen per year, a significant percentage of which reaches the protected areas or its surrounding, either directly from the settlement or from arable land. Since pastures surrounding Kumane for the most part belong to NP "Rusanda", towards which prevailing winds blow from the direction of Kumane (west and northwest winds), it is presumed that this protected area is most vulnerable to nitrogen deposition effects. Similar situation occurs with the amount of over 250 tons from Melenci, which, transported by the most frequent wind (southeast wind) and ground water, represents the key endangering factor for Rusanda Lake. The manure from Elemir with 136 tons of nitrogen has lower impact intensity on SNR "Okanj bara" due to deposition, than in the case of 66 tons from Taraš. In fact, the entire settlement of Taraš belongs to the zone up to $500 \mathrm{~m}$, while Elemir covers the area both inside and outside the 500$2000 \mathrm{~m}$ zone. The expected impact of Novi Bečej on SNR "Slano kopovo" is the lowest, considering that almost entire buildable land is located outside the analysed impact zone.

The current situation in protected areas with representation of the most vulnerable sites is given in Table 3. For the calculation of the amount of nitrogen compounds (according to field data), the value was adopted according to which livestock grazing in the pastures leave about $70 \%$ of their excretions annually. The data related to the sites where livestock stay are approximate (obtained by rounding off the figures to the nearest tenth) due to the occasional daily movements. In the NP "Rusanda" area, the exceedance of limit values was registered in two out of four separate sites (Fig. 1), both in terms of the number of livestock and the total amount of nitrogen. Both sites are located near Kumane, one (2R) northeast of the settlement, next to the K-29 canal $\left(\sum \mathrm{Nm}_{70} /\right.$ $\mathrm{ha}=177 \mathrm{kgN} /$ year), and the other $(3 \mathrm{R})$ in the direction of Melenci, towards so-called Great Rusanda $\left(\Sigma \mathrm{Nm}_{70} / \mathrm{ha}=269 \mathrm{kgN} / \mathrm{god}\right)$. If we take into account the fact that salt habitats are far more sensitive to eutrophication than other types of pasture areas (thus making the limit value of 170 $\mathrm{kgN} /$ year too high), we can say that another site (3O) west of Kumane (in the area of SNR "Okanj bara") with the value of $\Sigma \mathrm{Nm}_{70} / \mathrm{ha}=148 \mathrm{kgN} /$ year, as well as the third site $(4 \mathrm{R})$ within the NP "Rusanda" (near so-called Small Rusanda, $\Sigma \mathrm{Nm}_{70}$ / $\mathrm{ha}=115 \mathrm{kgN} /$ year), are also potentially threatened by nitrogen deposition. Part of the amount of nitrogen compounds of 360 tons from Kumane and 260 tons from Melenci most certainly contributes to the increment in the total annual amount on specific sites, particularly in the probable impact zone. At some vulnerable locations, negative changes were also registered in the population of some species which are exclusive indicators of salty habitats, as well as the occurrence of some invasive (aggressive alochthonous) species (Kicošev et al. 2012), which confirms the progressive

Table 2. The amount of total nitrogen in the aggregate amount of manure in settlements

\begin{tabular}{|c|c|c|c|c|c|c|c|c|c|c|c|}
\hline Settl & $\Sigma \mathrm{Bpc}$ & $\begin{array}{l}\Sigma \mathrm{Nmc} \\
(\mathrm{kgN} / \mathrm{god})\end{array}$ & $\Sigma \mathrm{Bps}$ & $\begin{array}{l}\Sigma \mathrm{Nms} \\
(\mathrm{kgN} / \mathrm{god})\end{array}$ & $\Sigma$ Bppi & $\begin{array}{l}\Sigma \mathrm{Nmpi} \\
\text { (kgN/god) }\end{array}$ & $\Sigma \mathrm{Bppl}$ & $\begin{array}{l}\Sigma \mathrm{Nmpl} \\
\text { (kgN/god) }\end{array}$ & $\Sigma \mathrm{Bpg}$ & $\begin{array}{l}\Sigma \mathrm{Nmg} \\
\text { (kgN/god) }\end{array}$ & $\begin{array}{l}\Sigma \mathrm{Nm} \\
(\mathrm{kgN} / \mathrm{god})\end{array}$ \\
\hline Melenci & 1500 & 151500 & 3800 & 45220 & 2300 & 27600 & 78000 & 25740 & 100 & 1500 & 251560 \\
\hline Kun & 3260 & 329260 & 850 & 10115 & 1760 & 21120 & 5000 & 1650 & 70 & 1050 & 3195 \\
\hline Elemir & 1150 & 116150 & 600 & 7140 & 800 & 9600 & 2500 & 825 & 165 & 2475 & 136190 \\
\hline Taraš & 470 & 47470 & 750 & 8925 & 600 & 7200 & 1500 & 495 & 120 & 1800 & 65890 \\
\hline N.Bečej & 375 & 37875 & 240 & 2880 & $\mathrm{NF}$ & 1 & NF & 1 & NF & ( & 40755 \\
\hline
\end{tabular}

Legend: $\Sigma \mathrm{B} p=$ Total number of livestock in the selected area: c-cattle, s-sheep, pi-pigs, pl-poultry, g-goats; $\Sigma \mathrm{Nm}=$ Aggregate amount of total nitrogen in manure; $\mathrm{NF}=\mathrm{Not}$ found 
Table 3. Isolate sites with increased possibility of nitrogen deposition

\begin{tabular}{|c|c|c|c|c|c|c|c|c|c|c|}
\hline \multirow{2}{*}{$\begin{array}{l}\text { Protected } \\
\text { Area }\end{array}$} & \multirow[t]{2}{*}{ Location } & \multirow{2}{*}{$\begin{array}{l}\mathrm{P} \text { (ha) } \\
\text { pasture }\end{array}$} & \multicolumn{2}{|l|}{$\Sigma \mathrm{Bpc}$} & \multicolumn{2}{|l|}{$\Sigma \mathrm{Bps}$} & \multirow{2}{*}{$\begin{array}{l}\Sigma \mathrm{Nm}^{70} / \mathrm{ha} \\
\text { (kgN/god) }\end{array}$} & \multirow{2}{*}{\begin{tabular}{|l|}
$\mathrm{LVc}$ \\
$(\mathrm{Bc} / \mathrm{ha})$
\end{tabular}} & \multirow{2}{*}{$\begin{array}{l}\text { LVs } \\
\text { (Bs/ha) }\end{array}$} & \multirow{2}{*}{$\begin{array}{l}\mathrm{LV} \\
(\Sigma \mathrm{Nm} / \mathrm{ha})\end{array}$} \\
\hline & & & In given area & Per 1ha & In given area & Per 1ha & & & & \\
\hline \multirow[t]{5}{*}{ NP "Rusanda" } & AUP & 1013 & 736 & 0.7 & 200 & 0.2 & 49 & & & \\
\hline & $1 \mathrm{R}$ & 70 & 120 & 1.7 & NF & 1 & 63 & & & \\
\hline & $2 \mathrm{R}$ & 100 & 250 & 2.5 & NF & 1 & 177 & & & \\
\hline & $3 R$ & 80 & 300 & 3.8 & NF & 1 & 269 & & & \\
\hline & $4 \mathrm{R}$ & 70 & 66 & 0.9 & 200 & 0.2 & 115 & & & \\
\hline \multirow{5}{*}{$\begin{array}{l}\text { SNR "Okanj } \\
\text { bara" }\end{array}$} & AUP & 4062 & 1480 & 0.4 & 600 & 0.1 & 29 & 1.7 & 14.3 & 170 \\
\hline & 10 & 200 & 220 & 1.1 & 50 & 0.3 & 81 & & & \\
\hline & 20 & 100 & 60 & 0.6 & NF & 1 & 43 & & & \\
\hline & 30 & 400 & 800 & 2 & 300 & 0.8 & 148 & & & \\
\hline & 40 & 1600 & 400 & 0.3 & 250 & 0.2 & 25 & & & \\
\hline \multirow{3}{*}{$\begin{array}{l}\text { SNR "Slano } \\
\text { kopovo" }\end{array}$} & AUP & 220 & 100 & 0.5 & 240 & 1 & 44 & & & \\
\hline & $1 \mathrm{~S}$ & 80 & 40 & 0.5 & 190 & 2.4 & 56 & & & \\
\hline & $2 \mathrm{~S}$ & 90 & 60 & 0.7 & 150 & 1.7 & 64 & & & \\
\hline
\end{tabular}

Legend: $\Sigma \mathrm{B} p=$ Total number of livestock in the selected area: $\mathrm{c}$-cattle, s-sheep; $\Sigma \mathrm{Nm}=$ Aggregate amount of total nitrogen in manure; $\mathrm{LV}=\mathrm{Limit}$ value (recommended); $\mathrm{NF}=\mathrm{Not}$ found

deterioration of habitat conditions. This resulted in deterioration of the quality of pastures necessary for the development of sustainable animal husbandry. Based on the analysis of field data, the situation in SNR "Slano kopovo" is still acceptable in terms of eutrophication. This situation most certainly occurs due to the small number of granges in the zone of immediate impact on the protected area and greater distance of the settlement. According to the aforementioned, the results of previous researches in this area (e.g. Petrović et al. 1984, 1986) show that the system of Slano Kopovo is less prone to changes in water quality than, for example, Rusanda.

What should be taken into consideration in estimating the actual load of nitrogen compounds is the fact that data obtained only for certain settlements (such as the number of geese which is about 1,000 in Melenci) were not included in the calculation. Starting from the value of $\mathrm{Km}_{\mathrm{pl}}$ (poultry), which is $0.33 \mathrm{kgN} /$ year per animal, the nitrogen amount in manure makes up the additional $330 \mathrm{kgN} /$ year load for Melenci. There is also a large number of cats and dogs in the settlements (e.g. according to unconfirmed reports from the field, there are about 1,500 dogs in the vicinity of SNR "Okanj bara"), but their exact number is unknown. Moreover, a significant amount of nitrogen originates from arable land stretching along the border with the protected areas, reaching the edge of the pasture area.

The data on the actual load of this ecologically sensitive area also have to include the amount of nitrogen filtered up to the first aquifer, including a significant amount of nitrogen originating from the municipal waste (permeable septic tanks are still used in the settlements, and the sewerage system infrastructure is still under construction), as well as from the manure. The problem of underground pollution spreading is most significant in Melenci, since extremely high level of ground water results in the occurrence of temporary or permanent marshiness in the urbanized area of the settlement. As the upper limit of the first aquifer is 1.5-2.5 $\mathrm{m}$ below the ground surface $(0.6 \mathrm{~m}$ in a part of the settlement next to Rusanda), the pollution at these localities has a direct impact on the lake water quality. It is important to emphasise that eutrophication is the most dominant problem in shallow standing water such as Rusanda Lake. Every increase in the nutrient content changes the composition of the water and sediment, thus changing the structure of saline ecosystems as well. These changes also affect the quality of peloids used for spa healing at the Special Rehabilitation Hospital "Rusanda".

\section{Conclusion}

Due to the improper manure management resulting in emission of significant amount of nitrogen, salt habitats of the protected areas in Central Banat have generally been very vulnerable. The vulnerability degree depends on the vicinity 
of settlements, individual granges and facilities for keeping animals (which are temporary in most cases). According to the results of the calculations, the most vulnerable locations which, for the most part, belong to the "Rusanda" protected area are: the pastures directly surrounding Kumane, pastures bordering Rusanda Lake, including the lake itself. A large number of cattle in comparison to available grazing areas directly surrounding the Kumane settlement may pose a threat to the quality of pastures in the northern part of SNR "Okanj bara". Negative changes in the populations of specific indicative species of saline habitats were detected on certain vulnerable sites, as well as the occurrence of invasive (aggressive alochthonous) species, which indicates progressive deterioration of habitat conditions. This resulted in the reduction in the quality of pastures necessary for the development of sustainable animal husbandry. On the other hand, increase in the nutrient content changes the composition of water and sediment of Rusanda Lake, which affects the quality of peloid used in spa healing.

For the purpose of protected area conservation, mainly habitats in NP "Rusanda", the possibility of future redistribution of Kumane livestock from especially vulnerable sites towards the less loaded parts of SNR "Okanj bara" is important to consider. For the ecological and developmental function of grazing as a form of animal husbandry, establishing grazing activities as an agro-ecological measure, for which agro-ecological payments could be introduced, is very important. Products from organic farming could have a special market value with the proper marketing support. Support is also available for non-profit investments related to the implementation of agro-ecological measures as well as limitations (e.g. resulting from the establishment of Natura 2000 network). By joining forces towards the common goal, agriculture and environment protection sectors can provide a solid base for the increase in competitiveness at the international level and create the possibility for the establishment of international connections. On the other hand, when Serbia obtains the status of EU membership candidate, it is expected that protected areas will have the priority in the utilization of international agro-ecological funds. Since the sector for organic agriculture is insufficiently funded at all levels, successful cooperation between several sectors could provide easier access to different international funds. This fact is very significant considering that government structures insufficiently recognize the potential of organic production during the reconstruction of agrarian sector in the process of accession to the European Union.
In the course of writing a management plan for the next period, it is necessary to evaluate all activities for the preservation of salt habitats. One of the most important activities is the reduction of nitrogen loss from manure by constructing appropriate storage facilities during the period of manure biotransformation and by proper use of arable land. In order to determine the habitat status in relation to the critical load, detailed analyses of the total and available nitrogen content should be conducted. The obtained data will be the basis for determining endangered habitats revitalization priorities.

\section{References}

Arbejdsrapport (2000). Critical loads. Conference Report 1999. Copenhagen. Prepared by Members of the Conference's Secretariat, the Scientific Committee and Chairmen and Rapporteurs of its Workshops in Consultation with the UN/ECE. Nr. 121.

http://www2.dmu.dk/1_viden/2_Publikationer/3_arbrapporter/rapporter/AR121.pdf.

Bobbink, R \& Hettelingh J.P. [eds] (2011). Review and revision of empirical critical loads and dose-response relationships. RIVM report 680359002. Netherlands: National Institute for Public Health and the Environment (RIVM), Coordination Centre for Effects.

http://www.rivm.nl/bibliotheek/rapporten/680359002.pdf.

Vall, M.P. \& Vidal C. [eds]. (2013). Nitrogen in agriculture. Agriculture and Rural Development. Brussels: European Comission. http://ec.europa.eu/agriculture/index_en.htm, Last update Oct.2013.

DEFRA (2009). Guidance for Farmers in Nitrate Vulnerable Zones: Standard values, manure sampling protocol and glossary. London: Department for Environment, Food and Rural Affairs. www.defra.gov.uk/environment/water/quality/nitrate.

EEA (2007). Halting the loss of biodiversity by 2010: proposal for a first set of indicators to monitor progress in Europe. Technical report No 11/2007.

http://www.eea.europa.eu/publications/technical_ report_2007_11/Last update Sep.2013.

Katić, B. [ed] (2008). Atlas vetrova AP Vojvodine. Novi Sad: Fakultet tehničkih nauka, Pokrajinski sekretarijat za energetiku i mineralne sirovine.

Ketterings, Q. M., Albrecht, G., Czymmek, K., \& Bossard, S. (2005). Nitrogen Credits from Manure. Fact Sheet 4, Nutrient Management Spear Program. New Work:Sciences Cornell University, College of Agriculture and Life, Department of Crop and Soil Sciences.

Kicošev, V. \& Sabadoš, K. (2007). Integracije zaštite prirode u perspektive održivog razvoja u Srbiji. Ecologica. Beograd: Naučno-stručno društvo za zaštitu životne sredine Srbije. 76-80

Kicošev, V., Belić, A. \& Veselinović, D. (2011a): Mogućnosti procene uticaja taloženja azotnih jedinjenja iz vazduha na komponente evropske ekološke mreže "Natura 2000", Kvalitet vazduha, monitoring, zakonska regulativa-rešenja, Zaštita vazduha 2011, Privredna komora Srbije, Zrenjanin, 115-126.

Kicošev, V., Radosavljević, M., Kovačević, N. \& Đukić, S. (2011b). Uloga analize zainteresovanih strana u održivom korišćenju budućih zaštićenih područja na primeru „Rusande“ i „Okanj bare“. Zaštita prirode, 61-2. Beograd: Zavod za zaštitu prirode Srbije 129-146.

Kicošev, V., Romelić, J. \& Matavuly, M. (2011c). Analysis of local stakeholders surrounding the future protected areas od Vojvo- 
dina in the function of sustainable rural development. Priroda 30. Praha: Agentura ochrany prirody a krajinu ČR. 151-166.

Kicošev, V., Bibin, M., Knežev, M., Kvaščev, M., Milivojev, I. \& Roljić, Z. (2012). Značaj učešća lokalnih zajednica u održivom razvoju okruženja ekološke mreže. Ecologica, 66. Beograd: Naučno-stručno društvo za zaštitu životne sredine Srbije. 145151.

Kicošev, V., Tucakov, M. \& Kovačev, N. [eds] (2012). Studija zastite Parka prirode „Rusanda“. Novi Sad: Pokrajinski zavod za zaštitu prirode.

Kicošev, V., Mesaroš, M., Veselinović, D., \& Sabadoš, K. (2013). Uspostavljanje zona unutar zaštitnih pojaseva prirodnih dobara u funkciji prilagođavanja na klimatske promene. Ecologica, 70. Beograd: Naučno-stručno društvo za zaštitu životne sredine Srbije. 181-187.

MPŠV (2011). Smanjenje zagadenja reke Dunav iz industrije u Srbiji (DREPR), Sporazum o donaciji iz trustovnog Globalnog fonda za zaštitu životne sredine br. TF 054908 i Sporazum o donaciji švedske vlade za ko-finansiranje projekta, donacija br. TF056212. Beograd: Ministarstvo poljoprivrede, šumarstva i vodoprivrede.

Noss, R.F. (2001). Beyond Kyoto: Forest management in a time of rapid climate change. Conservation Biology, 15/3: 578-590. http://noss.cos.ucf.edu/papers/Noss\%202001\%20climate. pdf.

Pavkov, G. [ed] (1999). Studija zaštite Specijalnog rezervata prirode „Slano kopovo". Beograd: Zavod za zaštitu prirode Srbije, Odeljenje Novi Sad.

Panjković, B. \& Kovačev, N. [eds] (2011). Studija zaštite Specijalnog rezervata prirode „Okanj bara". Novi Sad: Pokrajinski zavod za zaštitu prirode.

Petrović, O., Gajin, S., Gantar, M., \& Matavulj, M. (1984). Mikrobiološke karakteristike nekih autohtonih ekosistema slanih voda u Vojvodini; (Microbiological characteristics of some autochthonous ecosystems of saline waters in Voyvodina). Acta Biologica Iugoslavica, Series B. Mikrobiologija, 21, 1: 43-52. (In Serbian, English abstract).

Petrović, O., Matavulj, M., Gajin, S., \& Gantar, M. (1986). Mikrobiološka ispitivanja vode Rusande i Slanog kopa (Microbiological studies of water of Rusanda and Slano Kopovo) Plenarni referati i izvodi saopštenja VII Kongresa biologa Jugoslavije. Budva, 29.09.-30.10.1986, pp: 242-243. (In Serbian)

Pinho, P., Branquinho, C., Cruz, C., Tang, S., Dias, T. R., AP, Máguas, C., Martins-Loução, M. \& Sutton, M. (2009). Asses- sment of critical levels of atmospherically ammonia for lichen diversity in cork-oak woodland, Portugal. in: Atmospheric Ammonia - Detecting emission changes and environmental impacts - Results of an Expert Workshop under the Convention on Long-range Transboundary Air Pollution (eds. Sutton, M., Reis, S. and Baker, S.). Netherlands: Springer. 109-118.

Sala, O.E., Chapin III, F.S., Armesto, J.J., Berlow, E., Bloomfield, J., Dirzo, R., Huber-Sanwald, E., Huenneke, L.F., Jackson, R.B., Kinzig, A., Leemans, R., Lodge, D.M., Mooney, H.A., Oesterheld, M., Poff, N.L., Sykes, M.T., Walker, B.H., Walker, M. \& Wall, D.H. (2000). Global biodiversity scenarios for the year 2100. Science, 287. 1770-1774.

http://www.brown.edu/Research/ECI/people/sala/pdfs/Sala_ global_biodiversity_scenarios_2100.pdf.

Stoica, D.L., Sîrbu, C. \& Patriche, C.V. (2012). Continental salt land habitats conservation state related to natura 2000 sites. ro sci 0221 ileanavalley application, iaşi county. Present environment and sustainable development, 6, 2: 439-450.

http://www.academia.edu/2129670/continental salt land habitats_conservation_state_related_to_natura_2000_sites. ro_sci_0221_ileana_valley_application_iasi_county

Sutton, M.A., Reis, S. \& Baker, S.M.H. [eds] (2009). Atmospheric Ammonia- Detecting emission changes and environmental impacts. Netherlands: Springer Science. 464 pp. e-ISBN 7981-4020-9121-6.

Hannah, L., Midgley, G.F., Lovejoy, T., Bond, W.J., Bush, M., Lowett, J.C., Scott, D. \& Woodward, F.I. (2002). Conservation of biodiversity in a changing climate, Conservation Biology 16/1:264-268 doi: 10.1046/j.1523-1739.2002.00465.x.

Hicks, W.K., Whitfield, C.P., Bealey, W.J. \& Sutton M.A. (2011). Nitrogen Deposition and "Natura 2000"-Science and Practice in Determining Environmental Impacts. Workshop Proceedings. COST729/Nine/ESF/CCW/JNCC/SEI.

CACES (2012). Illinois Agronomy Handbook, Crop Science Extension \& Outreach, Chapter 9: Managing Nitrogen. University of Illinois at Urbana Champaign: College of Agricultural, Consumer, and Environmental Sciences.

CCE (2008). CCE Status Report 2008-Critical load, Dynamic Modelling and Impact Assessment in Europe, Coordination Centre for Effects, Netherlands Environmental Assessment Agency. http://www.rivm.nl/bibliotheek/rapporten/500090003. pdf/Last update Oct.2013.

\title{
Problematika određivanja količine istaloženih azotnih jedinjenja na slatinska staništa nacionalne ekološke mreže
}

\author{
Vesna Kicošev • Jovica Vasin • Milan Kvaščev • Miloš Bibin • \\ Ivan Bošnjak • Dragan Đukić • Laslo Senji
}

Izvod: Prekoračenja kritičnih opterećenja azotnim jedinjenjima se koriste kao indikatori rizika gubitka biodiverziteta od strane Evropske agencije za životnu sredinu. U radu je dat okvirni prikaz ugroženosti slatinskih staništa nacionalne ekološke mreže koja je uzrokovana taloženjem azotnih jedinjenja iz stajnjaka izabranih životinja, poreklom iz naselja koja se nalaze u okruženju zaštićenih područja srednjeg dela Banata. Za određivanje oblasti uticaja korišćeni su podaci o kratkom dometu taloženja azotnih jedinjenja, unutar dva pojasa: pojas verovatnog uticaja (od granice zaštićenog područja do $500 \mathrm{~m}$ ) i pojas mogućeg uticaja $(500-2000 \mathrm{~m})$. Na osnovu rezultata proračuna, kao posebno ugroženi lokaliteti izdvajaju se pašnjačke površine u neposrednom okruženju naselja Kumane koje najvećim delom pripadaju zaštićenom području „Rusanda“, pašnjaci uz Rusandu, kao i samo jezero.

Ključne reči: azotna jedinjenja, Banatska regija, ekološka mreža, slatinska staništa, taloženje, zaštićene oblasti 